\title{
群馬県合同輸血療法委員会輸血関連看護師会による輸血研修会 〜輸血療法の均てん化を目指して〜
}

\begin{tabular}{|c|c|c|c|c|c|c|}
\hline 坂倉＼cjkstart慶太 ${ }^{1)}$ & 伊藤 & 浩志 ${ }^{1)}$ & 寺田 & 誠1) & 上村 政彦1) & 横手 \\
\hline 橋＼cjkstart隆行3) & 中西 & 文江 $^{4)}$ & 猪越 & 朋美 ${ }^{5}$ & 冨賀見公美5) & 松本 \\
\hline 木＼cjkstart浩子6) & 今井 & 恵 ${ }^{7}$ & 尾沼 & 詩織8) & 健一1) & 横濱 \\
\hline
\end{tabular}

キーワード : 合同輸血療法委員会, 輸血研修会, 学会認定・臨床輸血看護師

\section{はじめに}

輸血における看護師の業務は，検査用検体の採取か ら輸血の準備・実施，患者の観察，輸血副反応一の対 応など他の職種に比べ幅広く，看護師の果たす役割は 大きい．輸血過誤の報告では，過誤の当事者として看 護師が最も多くなっておりり , 安全な輸血療法の実施に は患者に最も近いところで輸血に関与する看護師が正 しい知識と的確な看護能力を有することが重要である. 2010 年には, 臨床輸血に精通した看護師の育成を目的 として日本輸血・細胞治療学会による学会認定・臨床 輸血看護師制度が導入され22), 学会認定・臨床輸血看護 師（以下，臨床輸血看護師）がその知識と経験を活か し安全な輸血に寄与している。 しかし，輸血の頻度が 低い小規模施設においては, 臨床輸血看護師のいる施 設が少なく，院内の輸血教育が不十分であるため看護 師が不安を感じながら輸血業務を行っている現状があ $b^{3}$. 2018 年に群馬県赤十字血液センター (以下, 血液 センター）が輸血用血液製剤を供給した 145 施設のう ち $90.3 \%$ の 131 施設が 300 床未満の小規模施設であり, 群馬県合同輸血療法委員会（以下，合同輸血療法委員 会）によるアンケート調查をもとに実施した血液セン ター医薬情報担当者の訪問活動では「臨床輸血看護師 がおらず，疑問に思ったことを院内の誰に聞けば良い か分からない」「当院の輸血の実施方法が本当に正しい
のか不安に感じる」「輸血教育が十分とは言えない」と いった声を耳にした。

2018 年に群馬県合同輸血療法委員会輸血関連看護師 会（以下，看護師会）が発足し，輸血関連の認定資格 (学会認定・臨床輸血看護師, 学会認定・自己血輸血看 護師，学会認定・アフェレーシスナース）を取得して いる 14 施設 29 名で活動を開始した．所属する施設の 規模で見ると, 大規模 (500 床以上) 7 名, 中規模 (300 499 床) 16 名, 小規模 (299 床以下) 6 名となっている. 看護師会では, 年 4 回の情報交換会の開催や合同輸血 療法委員会による病院間相互訪問に視察員として参加 するなどの活動を行っているが，今回，県内の輸血に 携わる看護師が安全に輸血を実施できるよう，輸血看 護に関する知識・技術の向上を図るため輸血研修会を 開催した．参加者の輸血実施経験等の背景や満足度, 意見・要望を調查し，参加者のニーズに合ったより効 果的な研修会とするため, 研修会後に参加者にアンケー 卜調查を実施したので報告する。

\section{方法}

\section{1. 会場・日時}

会場へのアクセスを考え，前橋会場（前橋赤十字病 院）と太田会場 (太田記念病院)の 2 会場で開催した. 各会場で水曜日（19 時から 20 時 30 分）と土曜日（14

\footnotetext{
1）群馬県赤十字血液センター

2) 群馬大学医学部附属病院看護部

3）群馬大学医学部附属病院輸血部

4）前橋赤十字病院看護部

5）群馬県立がんセンター看護部

6）群馬県済生会前橋病院緩和ケア病棟

7）桐生厚生総合病院看護部

8）蜂谷病院看護部
}

〔受付日：2020 年 7 月 25 日, 受理日：2021 年 1 月 3 日〕 
表 1 輸血研修会の内容

\begin{tabular}{|c|c|c|c|}
\hline & 時間 & 内容 & 講師 \\
\hline $\begin{array}{l}\text { (1) } \\
\text { 輸血の基礎に } \\
\text { 関する講義 }\end{array}$ & 30 分 & 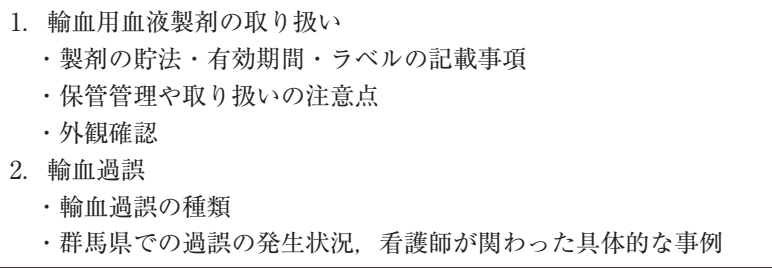 & 血液センター 医薬情報担当者 \\
\hline $\begin{array}{l}(2) \\
\text { 模擬バッグを } \\
\text { 使った実技研修 }\end{array}$ & $\begin{array}{l}10 \text { 分 } \\
\text { (講義) }\end{array}$ & $\begin{array}{l}\text { 1. 輸血の準備・実施の流れ } \\
\text { 2. 輸血セットの接続方法（動画：日本赤十字社作成） } \\
\text { 3. 患者の観察 } \\
\text { 4. 輸血実施時の注意点 }\end{array}$ & 看護師会 臨床輸血看護師 \\
\hline $\begin{array}{l}\text { (3) } \\
\text { 輸血のQ\&A に } \\
\text { 関する講義 }\end{array}$ & 15 分 & 参加者からの質問への回答 & $\begin{array}{l}\text { 看護師会 臨一床輸血看護師 } \\
\text { 血液センター 䒨薬情報担当者 }\end{array}$ \\
\hline
\end{tabular}

時から 15 時 30 分）の計 4 回開催し，実技研修を行う ことから参加人数は各回 50 名を上限とした.

\section{2. 内容}

過去に血液センターから輸血用血液製剤の供給実績 がある 241 施設の看護部門長宛に研修会の日時及び会 場，プログラムを記載した案内を事前に郵送した。

研修会の内容は以下のとおり 3 部構成で, 時間は各 部 30 分とした.

(1) 輸血の基礎に関する講義

血液センター医薬情報担当者が輸血用血液製剂を取 り扱う上での注意点や 2016 年に群馬県合同輸血療法委 員会が実施した輸血過誤の実態調査から輸血過誤の発 生状況・具体的な事例について講義した.

（2）模擬バッグを使った実技研修

群馬県での輸血過誤の実態調査において，看護師の 手技の誤りによるバッグの破損や血液漏れの事例が多 数見られたことから, 模擬バッグによる実技研修を行っ た．看護師会の臨床輸血看護師が輸血の実施方法につ いて動画を交えて講義し，その後，模擬バッグを使用 して正しい輸血方法と誤った輸血方法について実演し た．実技研修は，4６名を 1 グループとして各グルー プに看護師会の臨床輸血看護師 1 名を講師として配置 した。なお，模擬バッグ及び輸血セットは，血液セン ターで用意した。

（3）輸血の Q＆Aに関する講義

研修にあたり看護師会で「色調や内容量など輸血用
血液製剂に関すること」「輸血時の針の太さや加温の必 要性など輸血の実施に関すること」「輸血副反応発現時 の対応など副反応に関すること」について事前に Q\& A を準備, 作成した. 輸血の Q \& A に関する講義では, 看護師会の臨床輸血看護師が解説した後, 参加者から 当日集めた質問に対して回答を行った．参加者からの 質問をできるだけ促すように，研修会当日の受付の際 に質問用紙を配布した（表 1$)$.

全ての研修が終了した後，参加者にアンケート調査 を実施した。

\section{3. 倫理的配慮}

アンケートへの回答は自由意思に基づき, 無記名で 行った.アンケート結果の利用目的等について通知し 回答を以て同意とみなすことで，研究対象者が研究へ 参加することを拒否できる機会を設けた.

\section{結果}

計 4 回の輸血研修会で 52 施設 159 名の参加があり, 施設規模別では，小規模施設が $84.9 \%$ と最も多かった (図 1). 2018 年赤血球製剂供給単位数別の参加施設数 は, 100 単位以上 500 単位未満が最も多く，次いで 99 単位以下の施設であった。輸血療法委員会の設置率を 見ると，500 単位以上では $100 \%$ であったが，99 単位 以下では $46.7 \%$ と設置率が低かった (図 2). 参加者へ のアンケートでは, 155 名（回収率 $97.5 \%$ ) から回答を 得られた。 


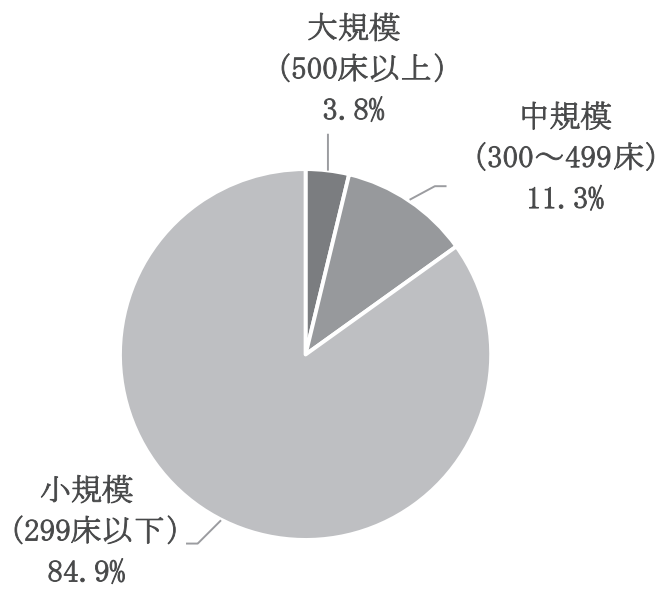

図 1 施設規模別の参加者の内訳

\section{1. 参加者の背景}

参加者の看護経験年数は, 16 年以上が $40.4 \%$ と最も 多く，10１5 年 (17.8\%) と合わせると 10 年以上の看 護経験者が $58.2 \%$ となり経験年数の長い参加者が多かっ た. 輸血実施経験のない参加者が $9.3 \%$, 輸血実施経験 ありと回答した参加者においても，36.9\% が年に 1〜2 回, $3.9 \%$ が年 1 回未満と輸血を扱う頻度が低かった。 参加理由は，「興味があった」が $53.8 \%$ で最も多く，次 いで「輸血を扱うことに対し不安があったから」が $23.1 \%$ であった（図 3 ).

\section{2. 満足度}

研修後のアンケート調査で「満足」あるいは「やや 満足」と回答した参加者が輸血の基礎に関する講義で は 93.3\%，実技研修で 87.1\%, Q\&A に関する講義では 93.0\% であったが, 一方で「普通」あるいは「やや不満」 や「不満」と答えた参加者がそれぞれ 6.7\%，12.9\%， $7.0 \%$ で実技研修に関してはやや満足度が低かった（図 4). 実技研修に関して「やや不満」「不満」と回答した 参加者の輸血を扱う頻度を見てみると, 主に週に 1 回 や月に 1〜2 回と定期的に輸血を扱う参加者であった (表 2).

\section{考察}

今回開催した研修会の参加者背景として，赤血球製 剂供給単位数が比較的少ない小規模施設に所属し, 輸 血実施経験がない，または実施経験があっても輸血を 扱う頻度が低い参加者が少なくなかったことから, 研 修会の参加理由として「輸血を扱うことに対し不安が あったから」との回答が「興味があった」に次いで多 かったと考えられる。

研修会に対する参加者の反応は概ね好評で，事後の アンケート調査では「满足」「やや満足」が多かった. 一方，本研修会の目的のひとつは，県内で報告されて

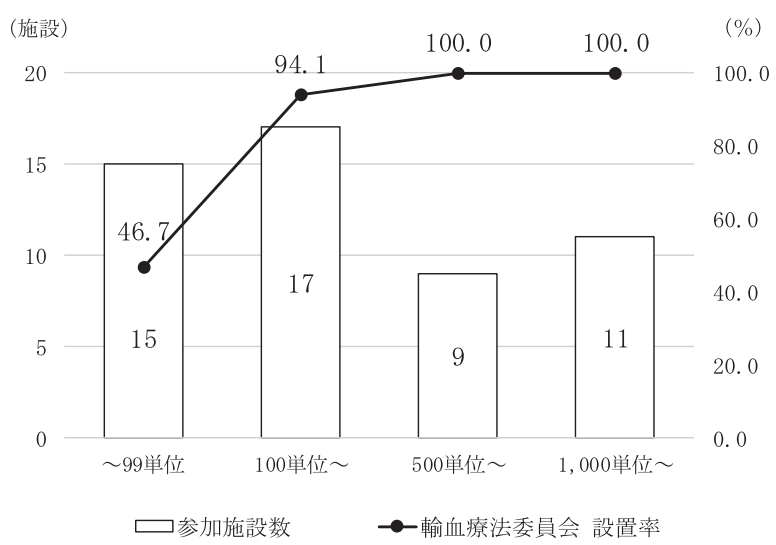

図 2 赤血球製剂供給単位数別の参加施設数と輸血療法委 員会設置率

いる手技の誤りによるバッグの破損や血液漏れといっ た過誤を防止することであり，そのために実技研修を 実施したが，輸血の基礎に関する講義や Q \& A に関す る講義に比べると実技研修で「やや不満」「不満」といっ た回答が多く見られた。「やや不満」「不満」と回答した 参加者は, 比較的輸血を扱う頻度が高かったことから, 輸血セットのつなぎ方といった基礎的な実技研修の内 容に不満であったと考えられる.「もう少し専門的な内 容かと思っていた」との意見も見られた.

事後のアンケート調査からいくつかの研修会の課題 が見えてきた。一つは，研修会の内容である，参加者 の知識・経験に差があるため, 参加者のレベルに合っ た研修内容が必要であり, 研修会を習熟度に合わせて 分ける必要があると思われた. また,「RBC 輸血後の副 反応について対処法を含めて詳しく知りたい」「 $\mathrm{ABO}$ 不適合輸血時の対応が知りたい」といった輸血副反応 についてより詳しい内容を希望する意見や「Type and Screen やクロスマッチなど輸血検査に関する内容も知 りたい」「自己血輸血についても教えて欲しい」との要 望があり，対応を考える必要がある(表 3 )。これらの ことから今後は初級と中級でレベルを分けて開催し, 初級については, 今回実施した研修会と同様の内容と する. 中級については, 実技研修の代わりにディスカッ ションの時間を設け, 輸血業務の中で疑問に思うこと を話し合い, 情報を共有する場としたい。講義の内容 は, 要望があった輸血副反応や輸血検査, 自己血輸血 の内容を盛り込むなどより専門的な内容としたい。習 熟度別の研修会については, 青森県合同輸血療法委員 会が対象を「臨床輸血看護師」「臨床輸血看護師の認定 試験受験者」「小規模施設に所属する看護師」と分けて 実施しており，参加者がレベルに合った知識を習得で き効果的であることが報告されている ${ }^{4)}$. 研修会の課題 として二つ目に，実技研修を行うため参加人数に 50 
（1）看護師の経験年数

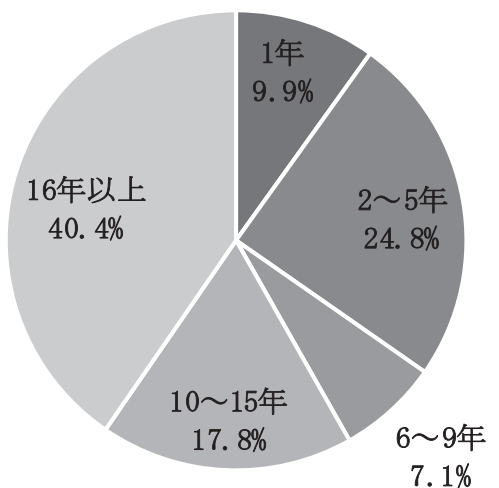

（3）輸血を扱う頻度

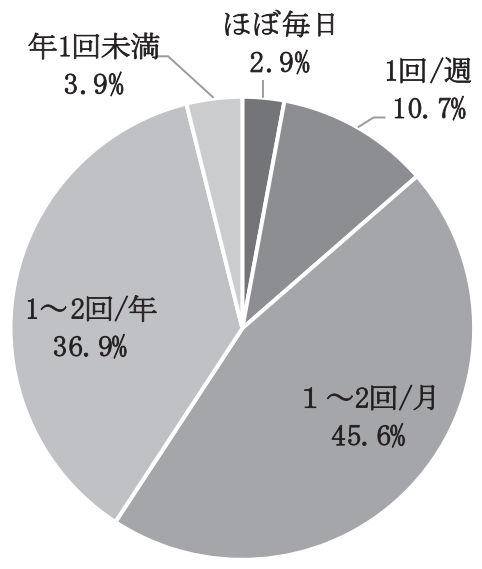

（2）輸血実施経験の有無

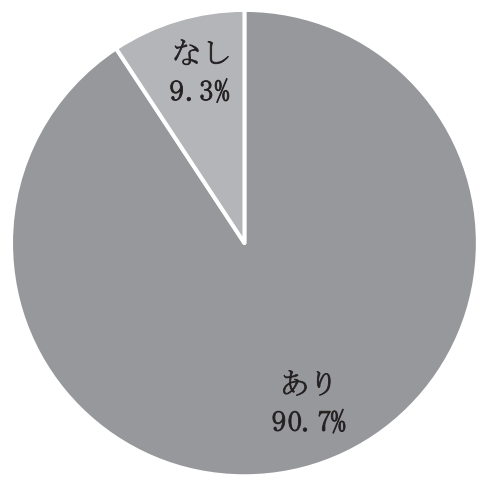

（4）参加理由

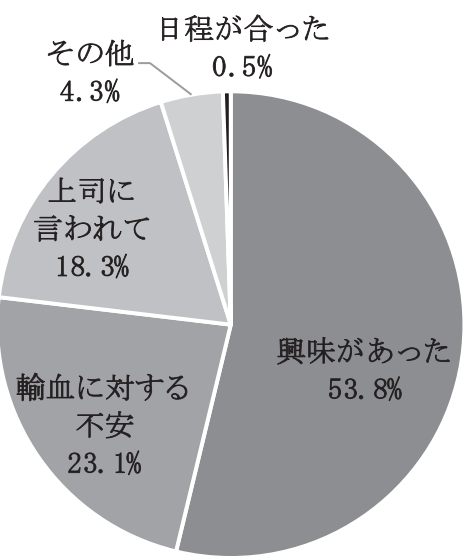

図 3 参加者アンケート (1) (参加者の背景)

輸血の基礎に関する講義

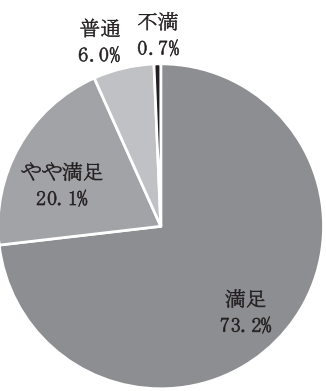

実技研修

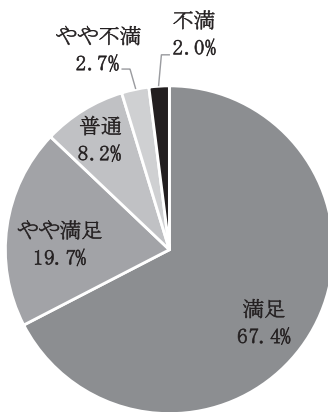

Q\&Aに関する講義

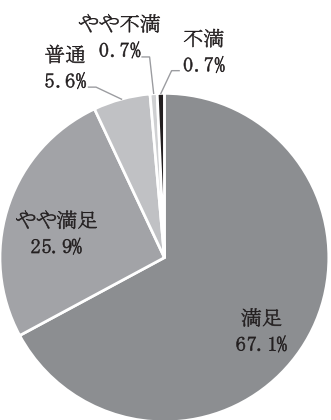

図 4 参加者アンケート(2) (参加者の満足度)

表 2 実技研修に「やや不満」「不満」と回 答した参加者の内訳

\begin{tabular}{|c|c|}
\hline 輸血を扱う頻度 & 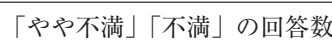 \\
\hline 1 回/週 & 3 \\
\hline $1 \sim 2$ 回/月 & 3 \\
\hline $1 \sim 2$ 回/年 & 1 \\
\hline
\end{tabular}

名という上限を設けたが, 定員を超える参加希望があっ たため，全ての参加希望に応えることができなかった ことである，定員増の検討や，同一施設で複数名の参 加があったことから施設ごとの上限人数の設定も検討 すべきである，三つ目に，質問を当日募集し Q\&A の講義で回答したが, 多くの質問が集まったため回答 を作成する時間が足りず対応が難しかった．今後は参 加の事前申し込み時に予め質問を募集するなどの対応 
表 3 研修内容に関する要望

\begin{tabular}{|c|c|}
\hline \multirow{6}{*}{ 講義 } & $\begin{array}{c}\text { ・基礎知識として輸血副反応についてもう少し詳しく知 } \\
\text { 到いい }\end{array}$ \\
\hline & $\begin{array}{l}\text { ・ RBC 輸血後の副反応について対処法を含めて詳しく } \\
\text { 知りたい }\end{array}$ \\
\hline & $\cdot \mathrm{ABO}$ 不適合輸血時の対応が知りたい \\
\hline & $\begin{array}{l}\text { ・輸血前の準備・手順（Type and Screen やクロスマッ } \\
\text { チど）に関する内知りたい }\end{array}$ \\
\hline & ·自己血の採血から保管, 使用までを教えて欲しい \\
\hline & •Q\&A の内容についてもっと詳細に知りたい \\
\hline \multirow{3}{*}{ 実技 } & ・実技に関する説明スライドをもう少し多くして欲しい \\
\hline & $\begin{array}{c}\text { ・輸血セットのフィルター部分に血液を満たすコツが知 } \\
\text { たたい }\end{array}$ \\
\hline & •実技の時間が長い \\
\hline
\end{tabular}

が必要であると考えられた。

今回, 看護師会として県内の臨床輸血看護師の協力 のもと研修会を実施した。臨床輸血看護師は, 自施設 の輸血教育やマニュアル作成など日々安全な輸血のた め尽力しているところではあるが，その臨床輸血看護 師が合同輸血療法委員会の活動に加わり, 知識や経験
を活かし，今回のような研修会を行えば県全体の輸血 の安全性向上と均てん化が期待される. 今回見えてき た研修会の問題点を改善し，今後も引き続き研修会を 行っていきたい.

著者の COI 開示: 坂倉慶太, 伊藤浩志, 寺田誠, 上村政彦, 丸 山健一：日本赤十字社職員

文献

1）米村雄士：輸血過誤の現状と対策. 日本輸血細胞治療学 会誌，58 (4)：518一-522, 2012.

2）日本輸血・細胞治療学会：学会認定・臨床輸血看護師制 度規約（平成 30 年 11 月 1 日改訂), 2010.

3）小田秀隆，東谷孝徳，新谷尚子，他：中小医療機関の看 護師を対象とした輸血研修会. 日本輸血細胞治療学会誌, 65 (1) : 108-111, 2019.

4）青森県合同輸血療法委員会：厚生労働省「平成 29 年度 血液製剂使用適正化方策調查研究事業」研究報告書, 2018,

\title{
EDUCATIONAL SEMINARS ON BLOOD TRANSFUSION FOR NURSES BY GUNMA PREFECTURAL JOINT COMMITTEE OF BLOOD TRANSFUSION THERAPY 〜FOR EQUALIZATION OF TRANSFUSION MEDICINE〜
}

\author{
${ }^{1)}$ Japanese Red Cross Gunma Blood Center \\ ${ }^{2)}$ Division of Nursing, Gunma University Hospital \\ ${ }^{3}$ Division of Blood Transfusion Service, Gunma University Hospital \\ ${ }^{4)}$ Department of Nursing, Maebashi Red Cross Hospital \\ ${ }^{5}$ Department of Nursing, Gunma Prefectural Cancer Center \\ ${ }^{6}$ Department of Palliative Care, Gunma Saiseikai Maebashi Hospital \\ ${ }^{7)}$ Department of Nursing, Kiryu Kosei General Hospital \\ ${ }^{8}$ Department of Nursing, Hachiya Hospital
}

Keita Sakakura $^{1)}$, Hiroshi Ito ${ }^{1)}$, Makoto Terada ${ }^{1)}$, Masahiko Kamimura ${ }^{1)}$, Keiko Yokote ${ }^{2)}$, Takayuki Maruhashi ${ }^{3}$, Fumie Nakanishi ${ }^{4)}$, Tomomi Inokoshi ${ }^{5)}$, Kumi Fukami ${ }^{5}$, Noriko Matsumoto $^{5}$, Hiroko Suzuki ${ }^{6}$, Megumi Imai ${ }^{7)}$, Shiori Onuma ${ }^{8)}$, Ken-ichi Maruyama ${ }^{1)}$ and Akihiko Yokohama ${ }^{3)}$

\section{Keywords:}

Joint committee of blood transfusion therapy, Transfusion educational seminar, Certified transfusion nurse

(C)2021 The Japan Society of Transfusion Medicine and Cell Therapy Journal Web Site: http://yuketsu.jstmct.or.jp/ 